\title{
Bioactivity of Lilium candidum L : A Mini Review
}

\author{
Jiri Patocka ${ }^{1,2 *}$ and Zdenka Navratilova ${ }^{3}$ \\ ${ }^{1}$ Department of Radiology, Toxicology and Civil Protection, Czech Republic \\ ${ }^{2}$ Department of Biomedical Research, Czech Republic \\ ${ }^{3}$ Department of Botany, Czech Republic
}

*Corresponding author: Jiri Patocka, Department of Radiology, Toxicology and Civil Protection, Czech Republic

\section{ARTICLE INFO}

Received: 幽 June 04, 2019

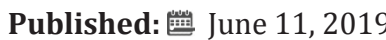

Citation: Jiri Patocka, Zdenka Navratilova. Bioactivity of Lilium candidum $L$ : A Mini Review. Biomed J Sci \& Tech Res 18(5)-2019. BJSTR. MS.ID.003204.

\begin{abstract}
The paper deals with Lilium candidum L., a well-known ancient plant in folk medicine for the treatment of burns, ulcers, inflammations and wound healing. The petals and bulbs of this plant contain many bioactive compounds. Many of them could also find their place in modern medicine.
\end{abstract}

Keywords: Lilium candidum; Traditional Medicine; Pharmacology

\section{Introduction}

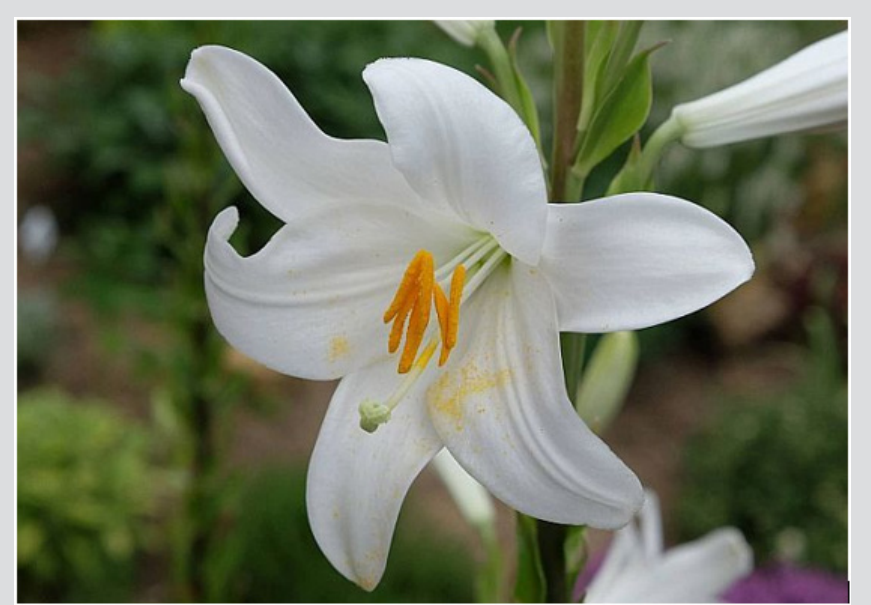

Figure 1: Blooming Lilium candidum L.

Lily (Lilium) is a genus of herbaceous flowering plants, consists of approximately 100 species, growing from bulbs. Most species are native to the temperate northern hemisphere. Lilies are tall perennials ranging in height from $60-180 \mathrm{~cm}$. Their flowers are large, often fragrant, and come in a wide range of colors. This plant are important in culture and literature in much of the Word Ziolkowski [1]. During the last 50 years, lily has become worldwide one of the most important flower bulbs and cut flowers. Lilium candidum, commonly known as Madonna lily is a symbol of purity and Inocence (Figure 1). This species of lily grows freely in Asia Minor and the Mediterranean, but in almost all countries of the world it is cultivated artificially for its modesty and beautiful flower. The lanceolate leaves grow from the ground rosette. The stem has straight, densely overgrown leaves and grows up to 70-150 $\mathrm{cm}$ in height. The flowers are up to 10 centimeters in size, bright white and smell great. Up to 15 flowers are arranged on one stem, arranged in grapes. Blooms in June and July. The fruits are capsules.

\section{Traditional Medicine}

The Lilium candidum L. is also an ancient plant, which is used as an important edible plant and important biomedicine in China to alleviate the symptoms of various human inflammatory diseases Jin et al. [2] and they are cultivated as an ornamental plant throughout the world. This plant helped from time immemorial in the treatment of inflamed and suppurative wounds, ulcers, skin inflammations, burns and various injuries Pieroni [3]. It is also used for muscle pain and gynecological problems. After surgery, it speeds up wound healing. Externally used is an alcohol or oil extract or crushed onions, internally onions cooked in water or milk Rigat et al. [4].

\section{Modern Medicine}

Mechanisms of Lilium anti-inflammatory activity and their bioactive components remain little known, but the therapeutic effects of lilies are confirmed by modern medicine, which has shown 
its healing, anti-inflammatory, analgesic, antioxidant, and other effects Vachalkova et al. [5-7]. Many biologically active substances were isolated from an ethanolic extract of flowers and onions of $L$. candidum. These are mainly flavonoids (quercetin, isorhamnetin, kaempferol) Tappi et al. [8], but numerous other bioactive substances have been found in the plant: carotenoids Tappi et al. [9] steroidal alkaloids, pyrrole alkaloids (lilalin, jatrophan), steroids (beta-sitosterol) and steroid saponins of furostane and spinostane type, tannins, polysaccharides, organic acids and amino acids Haladova et al. [10-19]. The structural formulas of some important Lilium compounds are shown in Figure 2.

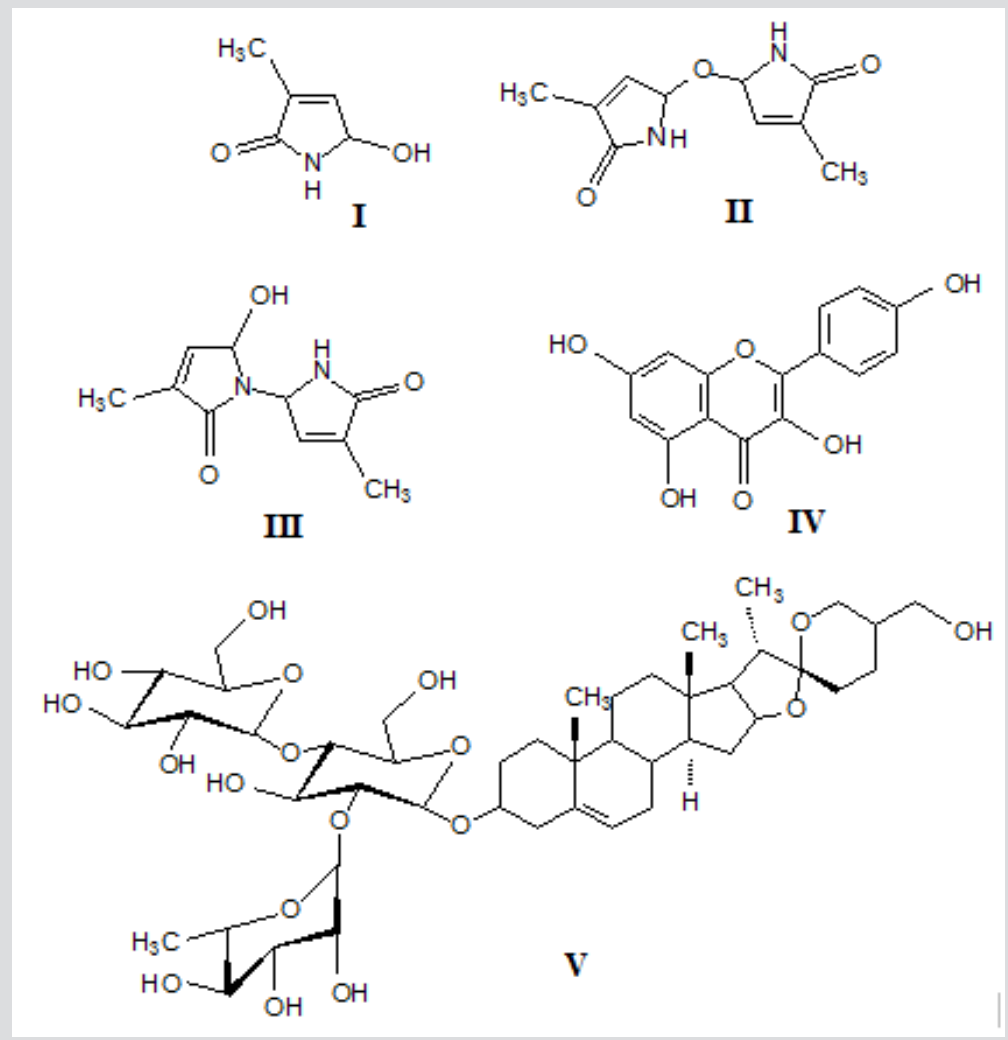

Figure 2: Important bioactive components of Lilium candidum.
a) Jatrophan,
b) 5-hydroxy-3-methyl-1-(3-methyl-2-oxo-3-pyrroline-5-yl)-3-pyrroline-2-on,
c) 5,5-oxydi-(3-methyl-3-pyroline-2-on),
d) kaempferol,
e) (25S)-3 $\beta$-\{ $\{\beta$-D-glucopyranosyl-(1 $\rightarrow 4)$-[a-L-rhamnopyranosyl-(1 $\rightarrow 2)]-\beta$-D-glucopyranosyloxy $\}$ spirost-5-ene-27-ol.

\section{Anti-Inflammatory Activity}

L. candidum extract is well known as an anti-inflammarory remedy for ulcers and burns and it is also proven means against healing of wounds Rasoulinezhad et al. [20]. Many steroids and steroid glycosides are likely to be responsible for the antiinflammatory effects of lilies Munafo et al. [21,22] Spirostanol and furostanol saponins were isolated from the fresh bulbs of $L$. candidum Mimaki et al. [14,15]. Beta-sitosterol and beta-sitosterol glucoside were isolated from the butanolic extract of petals $[14,15]$.

\section{Antitumor Activity}

Results of Tokgun et al. [23] indicate that L. candidum extracts have cytotoxic effects on human breast carcinoma cell line MCF7 cells and that this cytotoxic effect comes from $\mathrm{P}^{53}$-mediated stimulation of apoptosis. The anti-tumor effect may be due to the polysaccharide that were isolated by Han et al. [24] and which enhances immune function in $\mathrm{H} 22$ tumor bearing mice and inhibits H22 tumor growth. Also, alkaloids of showed cytotoxic activity against MCF-7 with $\mathrm{IC}_{50}$ of $244.8 \mu \mathrm{g} / \mathrm{ml}$ Al-Bayati [25].

\section{Hepatoprotective Activity}

The study of Devi et al. [26] have shown that the methanol extract of flowers of $L$. candidum contain some active ingredients with the hepatoprotective potential. The bioactive substance responsible for the hepatoprotective effect of this plant is unknown.

\section{Toxicology and Side Effects}

All parts of the plant are toxic in cats. Cats are the only species known to develop renal damage from lilies Bates et al. [27]. The mechanism of toxicity remains unknown Hall [28]. Pyrroline and 
pyrrolidine alkaloids of $L$. candidum may be enrolled in inducing signifiant oxidative stress and DNA damage, which lead to cell apoptosis or necrosis Al-Bayati et al. [25].

\section{Conclusion}

Lilium candidum $L$. with beautiful large white flowers is a species which grows in Asia Minor and the Mediterranean. It is a bulbous plant with beautifully scented flowers and is used in the floral industry and in folk medicine. The plant contains a number of bioactive substances that exhibit anti-inflammatory, cytotoxic, hepatoprotective and antitumor effects. This data could be useful for health research programs, particularly in clarifying the pharmacological potential and activity of natural plant compounds.

\section{Competing Interest}

The authors declare that they have no competing interests.

\section{Acknowledgment}

This work was supported by the long-term organization development plan of University Hospital, Hradec Kralove, Czech Republic.

\section{References}

1. Ziolkowski EJ, Lily III (2018) Literature and Music. In: de Gray W (ed). Encyclpedia of the Bible and Its Reception. 16: 678-683.

2. Jin L, Zhang Y, Yan L, Guo Y, Niu L (2012) Phenolic compounds and antioxidant activity of bulb extracts of six Lilium species native to China. Molecules 17(8): 9361-9378.

3. Pieroni A (2000) Medicinal plants and food medicines in the folk traditions of the upper Lucca Province, Italy. J Ethnopharmacol 70(3): 235-273.

4. Rigat M, Valles J, D Ambrosio U, Gras A, Iglesias J, et al. (2015) Plants with topical uses in the Ripollès district (Pyrenees, Catalonia, Iberian Peninsula): ethnobotanical survey and pharmacological validation in the literature. J Ethnopharmacol164: 162-179.

5. Vachalkova A, Eisenreichova E, Haladová M, Mucaji P, Józová B, et al. (2000) Potential carcinogenic and inhibitory activity of compounds isolated from Lilium candidum L. Neoplasma 47(5): 313-318.

6. Jarmolinsky L, Zakkai M, Ben Shabat S, Mills D, Huleihel M (2009) Antiviral activity of ethanol extracts of Ficus binjamina and Lilium candidum in vitro. N Biotechnol 26(6): 307-313.

7. Mallon R, Lorrain B, Corral P, Lota F, Michoux F (2016) Plant biotechnology, a sustainable source of bioactive compounds from Lilium candidum. Planta Medica 82(01): 776.

8. Tappi G, Karrer P (1949) Isorhamnetin aus den Staubblättern von Lilium candidum. Helv Chim Acta. 32(1): 322.

9. Tappi G, Karrer P (1949) Ueber die Carotinoide aus den Staubbeuteln von Lilium candidum, Cis-Antheraxanthin. Helv Chim Acta 32(1): 50-55.

10. Haladova M, Buckova A, Eisenreichova E, Uhrin D, Tomko J (1987) Jatropham in Lilium candidum L. Chem Papers 41: 835-837.
11. Haladova M, Buckova A, Eisenreichova E, Tomko J, Uhrin D, et al. (1991) Dimeric pyrroline alkaloids from Lilium candidum L. Collect Czech Chem Commun 56(2): 436-438.

12. Uhrin D, Buckova A, Eisenreichova E, Haladova M, Tomko J (1989) Constituents of Lilium candidum L. Chem Papers 43: 793-796.

13. Kuroda M, Sashida Y, Hatakeyama Y (1998) New steroidal constituents from the bulbs of Lilium candidum. Chem Pharm Bull (Tokyo) 46(11): 1829-1832.

14. Mimaki Y, Satou T, Kuroda M, Sashida Y, Hatakeyama Y (1998) New steroidal constituents from the bulbs of Lilium candidum. Chem Pharm Bull (Tokyo) 46(11): 1829-1832.

15. Mimaki Y, Satou T, Kuroda M, Sashida Y, Hatakeyama Y (1999) Steroidal saponins from the bulbs of Lilium candidum. Phytochemistry 51(4): 567-573.

16. Eisenreichova E, Haladova M, Mucaji P, Budesinsky M, Ubik K (2000) A new steroidal saponin from the bulbs of Lilium candidum L. Pharmazie 55(7): 549-550.

17. Mucaji P, Haladova M, Eisenreichova E, Budesinsky M, Ubik K (2000) Sterols in Lilium candidum L. Ceska Slov Farm 49(1): 29-31.

18. Mucaji P, Haladova M, Eisenreichova E, Budesinsky M, Ubik K (1996) Jatropham 5-0- $\beta$-D-glucopyranoside from Lilium candidum L. Collect Czech Chem Commun 61(11): 1662-1664.

19. Erdogan I, Sener B, Atta-ur-Rahman (2001) Etioline, a steroidal alkaloid from Lilium candidum L. Biochem Syst Ecol 29(5): 535-536.

20. Rasoulinezhad S, Yekta NH, Fallah E (2019) Promising pain-relieving activity of an ancient Persian remedy (mixture of white Lily in sesame oil) in patients with chronic low back pain. J Family Med Prim Care 8(2): 634.

21. Munafo Jr JP, Ramanathan A, Jimenez LS, Gianfagna TJ (2010) Isolation and structural determination of steroidal glycosides from the bulbs of Easter lily (Lilium longiflorum Thunb.). J Agr Food Chem 58(15): 88068813.

22. Munafo Jr JP, Gianfagna TJ (2015) Chemistry and biological activity of steroidal glycosides from the Lilium genus. Natural Prod Rep 32(3): 454477.

23. Tokgun O, Akca H, Mammadov R, Aykurt C, Deniz G (2012) Convolvulus galaticus, Crocus antalyensis, and Lilium candidum extracts show their antitumor activity through induction of p53-mediated apoptosis on human breast cancer cell line MCF-7 cells. J Med Food 15(11): 10001005

24. Han H, Xie HC (2013) A study on the extraction and purification process of lily polysaccharide and its anti-tumor effect. African J Trad Compl Allter Med 10(6): 485-489.

25. Al-Bayati N (2018) Antiproliferative Activity of Lilium candidum Alkaloid Extract on Human Breast Cancer Cell Line. J Pharm Sci Res 10(8): 20142016.

26. Devi NI, Kumar SN, Rajaram C (2016) Evaluation of hepatoprotective activity of Lilium candidum L. in experimental animal models. World J Pharmaceu Res 5(12): 725-749.

27. Bates N (2015) Lily toxicity in cats. Feline Focus 1(9): 333-337.

28. Hall JO (1992) Nephrotoxicity of Easter lily (Lilium longiflorum) when ingested by the cat. J Vet Intern Med 6: 121. 


\section{ISSN: 2574-1241}

DOI: 10.26717/BJSTR.2019.18.003204

Jiri Patocka. Biomed J Sci \& Tech Res

(C) This work is licensed under Creative

Submission Link: https://biomedres.us/submit-manuscript.php

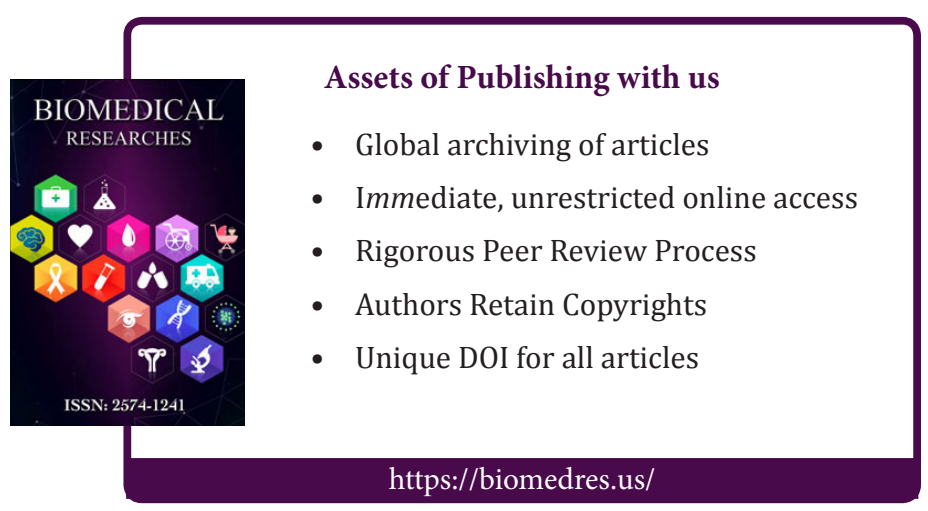

